\title{
THE IMPLEMENTATION OF GMP AND SSOP TOWARDS GIANT SEA CATFISH (ARIUS THALASSINUS) SMOKING PROCESS IN NORTH SEMARANG, SEMARANG CITY, INDONESIA
}

\author{
Susiana R.*, Darmanto Y.S., Swastawati F. \\ Master's Program in Coastal Resource Management, University of Diponegoro, Indonesia \\ *E-mail: rinisusiana.mpb97@gmail.com
}

\begin{abstract}
Giant sea catfish (Arius thalassinus) is a type of fish that has an added value once it is processed into smoked giant sea catfish. One of well-known delicacies from Semarang is "mangut ikan mayung" or smoked giant sea catfish with coconut milk, turmeric and chili. This study was conducted in Tambaklorok, Tanjungmas sub-region and Bandarharjo, North Semarang region, Semarang. Objectives of this study are to describe giant sea catfish (Arius thalassinus) smoking process in UPI and analyze how suitable GMP and SSOP are for giant sea catfish smoking process. The data collection method was survey while the data analysis method was qualitative descriptive. The sampling method was purposive sampling, conducted in 6 (six) UPIs. The finding stated that the producers did not apply either GMP or SSOP in the giant sea catfish (Arius thalassinus) smoking process. They used conventional methods to produce smoked giant sea catfish (Arius thalassinus).
\end{abstract}

\section{KEY WORDS}

Giant sea catfish, UPI, traditional, GMP, SSOP.

Giant sea catfish (Arius thalassinus) is a type of fish that has an important economic value and a chemical composition that varies greatly depending on its sex, age, sexual maturity and habitat as well as the fishing season. This fish provides a lot of benefits for human because it has high protein content and oil but low cholesterol. As an addition, giant sea catfish prevents several diseases such as heart problem, stroke and high cholesterol (Burhanuddin, et.al, 1987).

Giant sea catfish can potentially be used as an alternative type of protein and source of nutrients. Cooking methods determine nutrient content of giant sea catfish. The Ministry of Maritime Affairs and Fisheries (2014) reported that per capita fish consumption in the last five years keeps increasing. Between 2009 and 2013, fish consumption increased $20.83 \%$ from 29.08 kgs/capita into 35.14 kgs/capita (Nur Rohmah, et.al, 2015).

Fresh giant sea catfish smells pungent. However, smoked giant sea catfish is not only shiny and yellowish color, but it also has unique flavor and aroma (Ghazali, et. al, 2014). As the result, smoked giant sea catfish is one of the most favorite types of fish for Indonesian and people from foreign countries (Swastawati, 2011).

In Semarang, smoked fish business has a bright future. Tri Setyo, et.al (2013) stated that both smoked fish and its raw material are affordable. Besides that, raw materials for smoked fish business are easy to get because some parts of Semarang are located on the coast and as the result, most of the locals work as fishermen. Smoked giant sea catfish has added value, for example using smoked giant sea catfish as one of the ingredients to cook "ikan mangut" or smoked giant sea catfish with coconut milk, turmeric and chili and "kepala manyung pedas" or spicy giant sea fish head. These two are famous delicacies from Semarang.

Characteristics of fish smoking business in Semarang are it is using conventional methods, a small-scale business with low capital and does not pay close attention to sanitation or hygiene. Most people working in the fish smoking business has low background of education and as the consequence, they prefer using conventional method in their business (Yusroni, 2009). 
Based on the elaboration, the researchers are interested in analyzing implementation of GMP and SSOP towards quality control in giant sea catfish smoking process. The objective of this study is to analyze how much influence GMP and SSOP have towards giant sea catfish smoking business in Tambaklorok, Tanjungmas sub-region and Bandarharjo, North Semarang region, Semarang

\section{METHODS OF RESEARCH}

Data collection method was survey while data analysis method was descriptive qualitative. The sampling method was purposive sampling in 6 (six) UPI asap in Tambaklorok, Tanjungmas sub-region and Bandarharjo sub-region, North Semarang, Semarang. The samples were smoked giant sea catfish (Arius thalassinus).

\section{RESULTS AND DISCUSSION}

Quality Control, GMP and SSOP Implementation and Evaluation. Quality control consists of two parts, GMP and SSOP. GMP and SSOP are applicable for both modern and traditional fishing industry. The key to a qualified and safe product is an effective management system (Masrifah, et.al, 2015). GMP and SSOP evaluation is carried out through direct observation to the fish smoking business and interview using a modified GMP dan SSOP checklist for micro and small-scale UPIs. Article 5 of Peraturan Nomor 24/PERDJPDSPKP/2017 is used as the reference for categorizing SKP. The checklist classified any misconduct taking place during fish smoking process into critical, serious, major and minor misconduct. The researchers calculated total amount of misconduct in the UPIs and compared it to the standardized fish smoking process.

Both the observation, GMP and SOP checklists revealed that there are some misconduct taking place in the smoked giant sea catfish industry in North Semarang.

Based on smoked fish SNI 2725:2013, fish smoking process consists of raw materials, cleaning, scaling and deboning, fish brine, smoking, cooling, packaging and storing. GMP dan SSOP checklist showed that UPI A located in Tambaklorok, Tanjungmas sub-region has poor quality control. The researchers identified 1 (one) critical misconduct in which the toilet is connected directly to the fish smoking area. UPI B located in Tambaklorok as well as UPI $C, D, E$ and $F$ in Bandarharjo has fair quality control. The researchers did not find any critical misconduct but found 4 or fewer serious types of misconduct there. In general, all UPIs in North Semarang region are unable to meet the standardized quality control. The 1996 Food Law number 7 stated that it is mandatory for food producers to run quality control for food and food processing. Chapter II discusses significant influence of quality control towards both consumers and food producers, more particularly to protect their market, maintain customer loyalty and meet their targeted sales or profit.

Implementation of GMP for Quality Control. Table 1 discusses giant sea catfish smoking process in the 6 (six) UPIs.

Table 1 showed that one of the steps of the fish smoking process is fish brine in which the giant sea catfish is soaked into alum water for 5 to 10 minutes. The smoked fish producers believed that alum preserved texture of the fish and removed fish mucus effectively. Nurrahman and Isworo (2002)'s study showed that soaking mackerel tuna in alum water $\left(\mathrm{Al}_{2} \mathrm{SO}_{4} 14 \mathrm{H}_{2} \mathrm{O}\right)$ helped the fish texture becoming firm and removing its mucus. To remove excess water, fish is placed in plastic container for 10 minutes.

Water in Tambaklorok UPI comes from artesis while that in Bandarharjo UPI is from wells nearby. The water in Bandarharjo UPI turned into brackish water in the dry season but it remains clean and fresh in the rainy season. The smoked fish producers assumed that sea water has seeped into the soil. According to the Ministry of Public Health (2010) drinking water is safe when it meets the physical, microbiological, chemical and radioactive requirements as the mandatory and supplementary parameters. 
Table 1 - Giant Sea Catfish Smoking Process in North Semarang UPIs

\begin{tabular}{|c|c|c|}
\hline No. & Stage & Procedure \\
\hline 1. & $\begin{array}{l}\text { Raw } \\
\text { Material }\end{array}$ & $\begin{array}{l}\text { Purchasing giant sea catfish from fishermen or traditional market, storing the fish in ice-filled } \\
\text { containers and transporting the fish to the UPIs using pedicab, motorcyle/cars. These occur } \\
\text { in a relatively short time. }\end{array}$ \\
\hline 2. & Cleaning 1 & $\begin{array}{l}\text { Fish is put in buckets and water is poured on to the bucket to clean it. The water is taken } \\
\text { from a well nearby. }\end{array}$ \\
\hline 3. & Scaling & Fish gills and intestine are removed. The fish is cut into several large-sized pieces of fish. \\
\hline 4. & Fish Brine & $\begin{array}{l}\text { The fish is soaked into alum water for } 5 \text { to } 10 \text { minutes to get rid of its pungent smell and } \\
\text { mucus. }\end{array}$ \\
\hline 5. & Drying 1 & The fish is placed into plastic container for drying. \\
\hline 6. & Deboning & Removing the fish bones and cut it into a fillet. \\
\hline 7. & Cleaning 2 & $\begin{array}{l}\text { The fish fillet is placed into buckets and clean water is poured into the buckets to remove the } \\
\text { alum. }\end{array}$ \\
\hline 8. & Drying 2 & The fish is placed into plastic container for drying. \\
\hline 8. & Skewering & $\begin{array}{l}\text { Push skewer on the middle of the fish to prevent it from being damaged during smoking } \\
\text { process }\end{array}$ \\
\hline 9. & Preparation & Place the fish on flat metal frame. \\
\hline 10. & Smoking & $\begin{array}{l}\text { Smoking process lasts for } 15 \text { minutes. Workers should maintain the fire and flip the fish } \\
\text { several times so that the fish is cooked evenly. }\end{array}$ \\
\hline 11. & Cooling & Smoked fish is placed on flat bamboo frame or plastic container for cooling. \\
\hline 12. & Packaging & The smoked fish is packed using plastic or bamboo container. \\
\hline
\end{tabular}

Source: Data Collection, 2018.

Based on the observation, tools the UPls used during the smoking process did not meet GMP requirement. Yusra (2016)'s study reported unsuccessful implementation of GMP in "UPI ikan" located in Tiga Nagari, Tanjung Raya region, Agam Municipality can be traced back to lacking knowledge on fish as raw materials, smoking process, hygiene and sanitation.

Until recently, the smoked fish producers are still applying traditional smoking process. The process lasts for approximately 15 minutes and during the process the fish is flipped occasionally so that it cooks evenly. It is difficult to control the temperature because the UPIs do not have any smoking chamber. Therefore, a lot of smoke goes to waste. Table 2 summarizes implementation of GMP for the fish smoking process in North Semarang UPIs.

Implementation SSOP. Having analyzed implementation of SSOP for the giant sea catfish smoking industry in Tambaklorok, Tanjungmas sub-region and Bandarharjo subregion, North Semarang, it can be concluded that the fish smoking industry has a poor sanitation and hygiene standard. The industry applied a traditional smoking process that has been passed between generations. In other words, implementation of SSOP in the six UPIs in Tambaklorok and Bandarharjo did not run smoothly. Wulandari (2014) stated that there is a relationship between cleanliness of production utilities and production place, hand-washing habit and shelf life of smoked fish with number of bacteria found on the smoked fish. Susianawati, et.al (2007) investigating implementation of GMP and SSOP to maintain quality of product in salted fish industry in Kendal reported that low background of education and low socio-economic status are closely related to poor implementation of GMP and SSOP in the industry. Table 3 summarized implementation of SSOP in six giant sea catfish smoking industries in North Semarang.

Based on the field observation, laboratory analysis that investigates quality of water in Tambaklorok and Bandarharjo UPIs has not been conducted yet. Wulandari, et.al (2010) stated laboratory analysis is pivotal to decrease number of microbes and identify mineral content on certain body of water.

Most of the utensils in the fish smoking industry are hard to clean. The Ministry of Maritime Affair and Fisheries Decree (2013) stated that all equipments and utensils used during production and those with direct contact to fish should be rust-free, easy to clean, water resistant, non-toxic or should not cause any contamination towards both fish and processed food. 
Table 2 - Analysis on Implementation of GMP in 6 (Six) UPIs in North Semarang

\begin{tabular}{|c|c|c|c|}
\hline STAGE & GOAL & $\begin{array}{l}\text { PROCEDURE (Kepmen No. } 52 \\
\text { A/Kepmen-KP/2013 }\end{array}$ & CORRECTIVE STEPS \\
\hline 1 & 2 & 3 & 5 \\
\hline $\begin{array}{l}\text { Raw } \\
\text { Material }\end{array}$ & $\begin{array}{l}\text { To get fresh fish that } \\
\text { meets the standardized } \\
\text { weight }\end{array}$ & $\begin{array}{l}\text { Fish is transported from the market } \\
\text { quickly; } \\
\text { Fish is sorted based on its size; } \\
\text { Fish is tested for organoleptic; TPC } \\
\text { and E. Coli. }\end{array}$ & $\begin{array}{l}\text { *The giant sea catfish is } \\
\text { transported quickly and sorted } \\
\text { based on their size. The smoked } \\
\text { fish producers did not run } \\
\text { organoleptic, TPC or E. coli test } \\
\text { towards the fish }\end{array}$ \\
\hline Scaling & $\begin{array}{l}\text { To remove fish } \\
\text { intestines and gills }\end{array}$ & $\begin{array}{l}\text { Removing fish intestine and gills; } \\
\text { Fish is cleaned on a clean table, } \\
\text { sink or kitchen counter; } \\
\text { Scaling should be done carefully to } \\
\text { prevent any damage towards the } \\
\text { fish. }\end{array}$ & $\begin{array}{l}\text { Removing fish intestine and gills; } \\
\text { Fish is cleaned on the floor; } \\
\text { Scaling is done carefully. }\end{array}$ \\
\hline Fish Brine & $\begin{array}{l}\text { To clean the fish and } \\
\text { infuse some flavor to } \\
\text { the fish }\end{array}$ & $\begin{array}{l}\text { Fish is soaked in salt water or some } \\
\text { spices; } \\
\text { Fish brine takes place in a short time } \\
\text { and is done in careful manner. }\end{array}$ & $\begin{array}{l}\text { Fish is soaked in alum water for } 5 \\
\text { to } 10 \text { minutes in order to remove } \\
\text { its pungent odor and mucus }\end{array}$ \\
\hline Cleaning & $\begin{array}{l}\text { To get clean fish (raw } \\
\text { material) }\end{array}$ & $\begin{array}{l}\text { Each fish is cleaned under running } \\
\text { water or cold water; } \\
\text { The fish is stored in ice-filled } \\
\text { container. }\end{array}$ & $\begin{array}{l}\text { The producers did not use } \\
\text { running water to clean the fish; } \\
\text { The fish is stored in ice-filled } \\
\text { container }\end{array}$ \\
\hline Drying & $\begin{array}{l}\text { To dry fish from excess } \\
\text { water and get product } \\
\text { that meets particular } \\
\text { specification }\end{array}$ & $\begin{array}{l}\text { Fish is placed on a clean bamboo } \\
\text { frame for drying }\end{array}$ & $\begin{array}{l}\text { The fish is dried in a basket; } \\
\text { Push skewer on the middle of the } \\
\text { fish to prevent it from being } \\
\text { damaged during smoking } \\
\text { process. }\end{array}$ \\
\hline Smoking & $\begin{array}{l}\text { To get rid of harmful } \\
\text { bacteria or parasites } \\
\text { and get product that } \\
\text { meets particular } \\
\text { specification }\end{array}$ & $\begin{array}{l}\text { Fish is smoked until it is cooked } \\
\text { evenly. Smoking process should pay } \\
\text { attention to hygiene and sanitation } \\
\text { standards }\end{array}$ & $\begin{array}{l}\text { Smoking process lasts for } 15 \\
\text { minutes. The produces flipped the } \\
\text { fish several times so that it is } \\
\text { cooked evenly. }\end{array}$ \\
\hline Cooling & $\begin{array}{l}\text { To decrease fish } \\
\text { temperature between } \\
26^{0} \mathrm{C} \text { and } 30^{\circ} \mathrm{C}\end{array}$ & $\begin{array}{l}\text { Fish is stored in a closed container } \\
\text { at room temperature. }\end{array}$ & $\begin{array}{l}\text { Fish is placed on a clean bamboo } \\
\text { frame or plastic container for } \\
\text { cooling. }\end{array}$ \\
\hline Packaging & $\begin{array}{l}\text { To protect a product } \\
\text { during distribution or } \\
\text { storing process }\end{array}$ & $\begin{array}{l}\text { Product is stored in a basket to } \\
\text { prevent any contamination; } \\
\text { Product should be wrapped neatly in } \\
\text { a clean packaging }\end{array}$ & $\begin{array}{l}\text { Smoked fish is stored in } \\
\text { bamboo/plastic container and the } \\
\text { container is covered with a piece } \\
\text { of cloth. }\end{array}$ \\
\hline
\end{tabular}

Source: Data Collection, 2018.

Table 3 - Analysis on Implementation of SSOP in 6 (Six) UPIs in North Semarang

\begin{tabular}{|c|c|c|c|}
\hline STAGE & GOAL & PROCEDURE & CORRECTIVE STEPS \\
\hline 1 & 2 & 3 & 4 \\
\hline $\begin{array}{l}\text { 1. Quality of } \\
\text { water and ice }\end{array}$ & $\begin{array}{l}\text { To use clean and } \\
\text { boiled water to } \\
\text { make ice cubes } \\
\text { To use clean water, } \\
\text { which is water that } \\
\text { has met drinking } \\
\text { water standards, for } \\
\text { fish smoking }\end{array}$ & $\begin{array}{l}\text { Use clean and boiled water for fish smoking } \\
\text { industry, } \\
\text { Clean water refers to water that has met drinking } \\
\text { water standards } \\
\text { Water is divided into two types; the first is water } \\
\text { used to clean fish and other ingredients and the } \\
\text { second is water used to clean kitchen utensils } \\
\text { Water does not contain any harmful chemicals or } \\
\text { harmful living organism. }\end{array}$ & $\begin{array}{l}\text { Artesian water is used to make ice } \\
\text { cube; } \\
\text { Ice cube is stored in refrigerator; } \\
\text { Water hose is used to get water } \\
\text { from the water source } \\
\text { The smoked fish producers did not } \\
\text { run any analysis on quality of } \\
\text { water they used; } \\
\text { The producers did not distinguish } \\
\text { water they used to clean the fish } \\
\text { and other ingredients from that } \\
\text { they used to clean the kitchen } \\
\text { utensils. }\end{array}$ \\
\hline
\end{tabular}




\begin{tabular}{|c|c|c|c|c|}
\hline $\begin{array}{l}\text { 2. Cleanliness } \\
\text { of surface that } \\
\text { contacts food } \\
\text { items }\end{array}$ & $\begin{array}{l}\text { 1. Production site, } \\
\text { including } \\
\text { surrounding } \\
\text { environment, meets } \\
\text { the sanitation and } \\
\text { hygiene standard } \\
2 \text {. To make sure } \\
\text { that all surface that } \\
\text { contacts food item } \\
\text { is clean and } \\
\text { hygienic }\end{array}$ & \multicolumn{2}{|c|}{$\begin{array}{l}\text { Production site is clean and hygienic } \\
\text { Production site is free from any pollutant } \\
\text { Production site floor is tilted to avoid any puddle } \\
\text { Surface of the floor is smooth and easy to clean } \\
\text { Production site ceiling is in good condition and } \\
\text { easy to clean } \\
\text { Surface of production site wall is waterproof and } \\
\text { smooth } \\
\text { Production site window is in good condition. It } \\
\text { shuts properly and prevents water from coming } \\
\text { into production site. } \\
\text { Production site door is in a good condition. It } \\
\text { shuts properly. } \\
\text { Production site electricity (including lamps) works } \\
\text { properly. } \\
\text { Air circulation works properly } \\
\text { Sanitation and hygiene prior to and after } \\
\text { production has always become a priority } \\
\text { Production utilities are clean and hygienic, rust- } \\
\text { free, oil-free, and germ-free. } \\
\text { Food grade detergent is used to clean production } \\
\text { utilities prior to and after production }\end{array}$} & $\begin{array}{l}\text { There is paved street around the } \\
\text { UPIs } \\
\text { The UPIs are closed to the rivers } \\
\text { The UPIs are located in residential } \\
\text { area } \\
\text { The producers did not use window } \\
\text { mesh to cover the UPI windows or } \\
\text { air vent } \\
\text { The UPI buildings are made of } \\
\text { food, including their walls and } \\
\text { floors. } \\
\text { The concrete floor is uneven and } \\
\text { thus, is difficult to clean. Burn } \\
\text { residue stuck to the floor } \\
\text { Production utilities are not stored } \\
\text { in a special container } \\
\text { The UPI doors are made of wood } \\
\text { and the producers did not use } \\
\text { door mesh to cover the doors } \\
\text { Smoking equipment is made of } \\
\text { iron and thus is difficult to clean } \\
\text { Instead of food grade detergent, } \\
\text { the producers clean their } \\
\text { production utilities using water } \\
\text { from nearby wells }\end{array}$ \\
\hline \multicolumn{2}{|c|}{ 3. Cross-contaminate-ion prevention } & $\begin{array}{l}\text { To prevent cross- } \\
\text { contamination from } \\
\text { production site and } \\
\text { production site workers }\end{array}$ & $\begin{array}{l}\text { To apply personal } \\
\text { hygiene (smoking-free } \\
\text { environment, } \\
\text { maintaining acceptable } \\
\text { noise level, washing } \\
\text { hands after using the } \\
\text { toilet, not wearing any } \\
\text { jewelry, washing hands } \\
\text { after touching any } \\
\text { object that may } \\
\text { potentially be non- } \\
\text { hygienic } \\
\text { Wearing uniform (head } \\
\text { cover, face mask, } \\
\text { closed-toe shoes) } \\
\text { during production } \\
\text { Separating raw } \\
\text { materials from } \\
\text { processed goods during } \\
\text { food preparation, } \\
\text { production and storing } \\
\text { Creating enough space } \\
\text { between raw material } \\
\text { storage and processed } \\
\text { goods storage } \\
\text { Sufficient waste } \\
\text { management } \\
\text { Clear job assignment } \\
\text { among workers } \\
\end{array}$ & $\begin{array}{l}\text { The producers are using food waste } \\
\text { for fish feed } \\
\text { The workers cleaned all utensils } \\
\text { right after production } \\
\text { The workers wore their own clothes } \\
\text { during production } \\
\text { The workers washed their hands } \\
\text { prior to production } \\
\text { The raw material and processed } \\
\text { goods (smoked fish) were stored } \\
\text { separately (the producers never } \\
\text { stored the raw material for more } \\
\text { than one day) } \\
\text { The preparation and production } \\
\text { were conducted in the same room. } \\
\text { The UPIs did not have separate } \\
\text { room for each stage of production }\end{array}$ \\
\hline \multicolumn{2}{|c|}{$\begin{array}{l}\text { 4. Cleanliness of sink, sanitation } \\
\text { system and the toilet }\end{array}$} & $\begin{array}{l}\text { To make sure worker's } \\
\text { hygiene level }\end{array}$ & $\begin{array}{l}\text { Sink has running water, } \\
\text { is not clogged and has a } \\
\text { closed-lid waste bin } \\
\text { Sufficient changing } \\
\text { rooms for production } \\
\text { workers. } \\
\text { Production site has a } \\
\text { facility that separates } \\
\text { workers' clothes form } \\
\text { their working uniform }\end{array}$ & $\begin{array}{l}\text { The UPIs did not have any } \\
\text { changing room or sink for washing } \\
\text { hands in production area } \\
\text { All waste goes straight to the river } \\
\text { The toilet is very close to production } \\
\text { area. The UPIs did not provide any } \\
\text { closed-lid waste bin or hand soap }\end{array}$ \\
\hline
\end{tabular}




\begin{tabular}{|c|c|c|c|}
\hline 5. Protection against contaminants & $\begin{array}{l}\text { All food items (both raw } \\
\text { materials and processed } \\
\text { food) and surface that } \\
\text { contacts food items are } \\
\text { free from germ, } \\
\text { chemicals and physical } \\
\text { contaminant }\end{array}$ & $\begin{array}{l}\text { Make sure that air } \\
\text { ventilation works well to } \\
\text { prevent condensation } \\
\text { During production, } \\
\text { workers should control } \\
\text { and get rid of food items } \\
\text { that may cause } \\
\text { contamination } \\
\text { Store food items and } \\
\text { sanitary items in } \\
\text { separate rooms } \\
\text { Empty close-lid trash bin } \\
\text { regularly. The trash bin } \\
\text { is placed away from } \\
\text { production area } \\
\text { Food processing and } \\
\text { food storing (both raw } \\
\text { materials and processed } \\
\text { goods) }\end{array}$ & $\begin{array}{l}\text { The producers store raw materials, } \\
\text { processed food and other } \\
\text { ingredients in the same room } \\
\text { The UPIs have windows and air } \\
\text { ventilation for circulation } \\
\text { Trash bins are located away from } \\
\text { the producing area (fish smoking } \\
\text { area) }\end{array}$ \\
\hline $\begin{array}{l}\text { 6. Labeling, storing and using toxic } \\
\text { ingredient carefully }\end{array}$ & $\begin{array}{l}\text { Appropriate labeling, } \\
\text { storing and use of toxic } \\
\text { ingredients to avoid } \\
\text { contamination }\end{array}$ & $\begin{array}{l}\text { Toxic ingredients should } \\
\text { have label and clear } \\
\text { description about their } \\
\text { content and application } \\
\text { Toxic ingredient is } \\
\text { labeled and stored into a } \\
\text { box with particular label } \\
\text { or sticker }\end{array}$ & $\begin{array}{l}\text { There are several unlabelled toxic } \\
\text { ingredients around the processing } \\
\text { area (fish smoking area) }\end{array}$ \\
\hline 7. Worker's health examination & $\begin{array}{l}\text { Identify workers who } \\
\text { show symptoms of } \\
\text { illness, injury or other } \\
\text { conditions that may } \\
\text { cause contamination }\end{array}$ & $\begin{array}{l}\text { Establish internal } \\
\text { regulation for sick } \\
\text { employees }\end{array}$ & All UPI workers are healthy \\
\hline 8. Pest control & $\begin{array}{l}\text { Pest, extermination } \\
\text { (including rodents, birds, } \\
\text { and insect). }\end{array}$ & $\begin{array}{l}\text { Pest extermination in } \\
\text { UPI and surrounding } \\
\text { areas } \\
\text { Prevent pests (rodent, } \\
\text { bird and insect) from } \\
\text { entering fish smoking } \\
\text { area } \\
\text { Prepare pest } \\
\text { extermination process }\end{array}$ & $\begin{array}{l}\text { UPI has not administered any pest } \\
\text { extermination method yet }\end{array}$ \\
\hline
\end{tabular}

Source: Data Collection, 2018.

The UPI workers did not wear certain uniform to work. The workers in Tambaklorok UPI did not wear any head cover but those in Bandarharjo UPI did. Based on the Ministry of Maritime Affair and Fisheries Decree (2013), production workers should wear clean uniform and head cover at work.

Tambaklorok UPI is located in residential area. The smoking area is far from hygienic. Tambaklorok UPI building, including the air ventilation, is made of wood and bamboo. It does not have any ceiling either. A lot of burn residue and spider web stuck to the roof and building frame making the building dark. It means that the UPI workers hardly clean the building. This may cause contamination because the fish is stored in an open basket. The concrete floor is uneven and the UPI workers patched it with soil. The Ministry of Maritime Affair and Fisheries Decree (2013) stated that UPI must not be built in a residential area, industrial area or any area that may cause contamination to processed goods is prohibited. Production site, including fish smoking area, should meet certain criteria. First, production site floor should be waterproof and tilted making it easier to clean. Secondly, production site wall surface should also be waterproof, strong yet smooth and more importantly, easy to clean. The third is production site door should be made of wood or other materials and easy to clean. In addition, production site ceiling and building firm should be cleaned regularly. Furthermore, air ventilation is important to avoid condensation and provide enough sunlight for production site. However, most of the UPIs in North Semarang have yet been able to meet SSOP requirements.

UPI A Tambaklorok toilets are facing the production area directly while UPI $B$ Tambaklorok toilets are located outside the building, away from the production area. The 
toilets in UPI C, D, E and F in Bandarharjo are located inside the building but separated from the production area. Nurcahya Dewi (2018) and Ministry of Maritime Affair and Fisheries Decree (2013) encourage production workers to pay close attention to their personal hygiene, quality assurance and food safety. Toilet should not face production area and the UPIs should provide enough toilet stalls for all of their workers.

All UPIs do not provide hygiene facilities for their employees. Based on the Ministry of Maritime Affair and Fisheries Decree (2013), production site should have automated hand washing facilities where workers wash their hand prior to and after production. Handwashing, sanitation and toilet facilities are important since these prevent food contamination during production. Lacking hygiene facilities may cause serious bacterial contamination to processed goods (food).

Food contamination is a serious issue in food production. Biological, physical and chemical factors may cause food contamination. Nurcahya Dewi (2018) explained that cross contamination is to transfer biological or chemical contaminant from sources of contamination to food item. The researchers found chemical that may cause food contamination in Bandarharjo UPI but did not find any in Tambaklorok UPI. The researchers found alum, a chemical substance, in Bandarharjo UPI. Ministry of Maritime Affair and Fisheries Decree (2013) stated that UPI must consult the law and regulation on food and food production prior to using any additional ingredient for production. In addition, the UPI should establish a criterion to avoid biological, chemical and physical contamination based on not only the law and regulation on food and food production but also its product specification.

All of the UPIs did not label their products or ingredients they use properly either. Ministry of Maritime Affair and Fisheries Decree (2013) emphasized on importance of labeling or product description for product traceability.

Some animals, rats, cockroaches, flies, lizard and cats, disturbed the fish smoking process in Tambaklorok and Bandarharjo UPIs. These animals and lack of pest control may cause cross contamination. Ministry of Maritime Affair and Fisheries Decree (2013) stated that food producers should administer pest control method to avoid cross contamination.

\section{CONCLUSION}

Based on the finding, it can be concluded that the giant sea catfish (Arius thalassinus) smoking industry in Tambaklorok, Tanjungmas sub-region and Bandarharjo sub-region, North Semarang is running based on traditional method. The smoked fish producers did not use either GMP or SSOP for quality control.

\section{REFERENCES}

1. Burhanudin, A.D., Martosewojo, S., Hoetomo, M. 1987. Sumber Daya IkanManyung di Indonesia. LON-LIPI. Jakarta.

2. Ghazali, R.R., F. Swastawati \& Romadhon. 2014. Analisa Tingkat Keamanan Giant sea catfish (Arius Thalassinus) Asap Yang Diolah Dengan Metode Pengasapan yang Berbeda. Jurnal Pengolahan dan Bioteknologi Hasil Perikanan, 3 (4): 31-38.

3. Masrifah, E., B.P. Noorachmat \& A. Sukmawati. 2015. Kesesuaian Penerapan Manajemen Mutu Ikan Pindang Bandeng (Chanos chanos) Terhadap Standar Nasional Indonesia. Jurnal Manajemen IKM, 10(2): 163-172.

4. Nurcahya Dewi, Eko. 2018. Materi Penerapan Prosedur Sanitasi (SSOP) pada Pengolahan Hasil Perikanan. Kegiatan Bimbingan Teknis Penerapan Sistem Jaminan Mutu dan Keamanan Hasil Perikanan Bagi Pembina Mutu Daerah. Research Report, Dinas Kelautan dan Perikanan Provinsi Jawa Tengah, August 2, 2018.

5. Nurrahman \& J.T. Isworo. 2002. Pengaruh Lama Perendaman dan Konsentrasi Tawas Terhadap Sifat Fisik, Kimia dan Organoleptik Ikan Tongkol Asap. Proceeding, Seminar Teknologi Pangan. PATPI, Malang, Indonesia. 
6. Nur Rohmah, D.Y., Y.S. Darmanto \& U. Amalia. 2015. Karakteristik Lem Dari Tulang Ikan Dengan Habitat Yang Berbeda (Payau, Tawar, Laut). Jurnal Pengolahan dan Bioteknologi Hasil Perikanan, 4(2): 11-16.

7. Susianawati, R., L. Sya'rani, \& T.W. Agustini. 2007. Kajian Penerapan GMP dan SSOP Pada Produk Ikan Asin Kering Dalam Upaya Peningkatan Keamanan Pangan Di Kabupaten Kendal. Jurnal Pasir Laut, 2(2): 40-53.

8. Swastawati, F. 2011. Studi Kelayakan Dan Efisiensi Usaha Pengasapan Ikan Dengan Asap Cair Limbah Pertanian. Jurnal Dinamika Ekonomi Pembangunan, 1(1): 18-24.

9. Tri Setyo, A., Sumartini, M. Syarifuddin, dan F. Swastawati. 2013. Penerapan Tungku Sierra Leone Sebagai Alternatif Pengentasan Kemiskinan Pada Sentra Pengasapan Mangunharjo Semarang. Jurnal Saintek Perikanan, 9 (1): 1-6.

10. Wulandari, B. 2014. Hubungan Antara Praktek Higiene Dengan Keberadaan Bakteri Pada Ikan Asap Di Sentra Pengasapan Ikan

11. Bandarharjo Kota Semarang Tahun 2013. Unnes Journal Of Public

12. Health, 3(2):1-10.

13. Wulandari, D.A., I.W. Abida, A. Farid. 2010. Kualitas Mutu Bahan Mentah dan Produk Akhir Pada Unit Pengalengan Ikan Sardine di PT. Karya

14. Manunggal Prima Sukses Muncar Banyuwang. Jurnal Kelautan, 2(1) : 4049.

15. Yusra. 2016. Kajian Penerapan GMP Dan SSOP Pada Pengolahan Ikan Nila (Oreochromis niloticus) Asap Di Kecamatan Tanjung Raya Kabupaten Agam. Jurnal Katalisator Kopertis Wilayah X Kementerian Riset Teknologi Dan Pendidikan Tinggi, I (1): 10-19.

16. Yusroni, N. 2009. Analisis Profit Margin Untuk Meningkatkan Nilai Tambah Pendapatan Antar Pengrajin Pengasapan Giant sea catfish, Ikan Tongkol dan Ikan Pari Di Bandarharjo Semarang.Fakultas Ekonomi Universitas Wahid Hasyim Semarang. Jurnal Ekonomi dan Bisnis, 4(8). 